\title{
Rootstock Effects on Deficit-Irrigated Winegrapes in a Dry Climate: Vigor, Yield Formation, and Fruit Ripening
}

\author{
Markus Keller, ${ }^{1 *}$ Lynn J. Mills, ${ }^{2}$ and James F. Harbertson ${ }^{3}$
}

\begin{abstract}
A rootstock field trial was conducted in the Yakima Valley, southeastern Washington, with three Vitis vinifera cultivars (Merlot, Syrah, Chardonnay). Vines were grown on their own roots or field-grafted to the rootstocks 5C, 99R, 140Ru, 1103P, 3309C, and an unnamed rootstock from Cornell University (here termed 101CU) that is a likely sibling or seedling of 101-14 Mgt. Repeated scion dieback due to cold injury to 99R led us to abandon this rootstock. Vine phenology, vigor, water status, yield formation, and fruit ripening and composition were evaluated during three years beginning in the vineyard's ninth year. Own-rooted Merlot and Chardonnay grew more shoots than grafted vines, and 140Ru and 1103P tended to reduce pruning weights. However, 3309C was the rootstock associated with the highest pruning weights in Syrah and the lowest in Chardonnay. Rootstocks usually did not impact vine phenology, fruit set, and plant water status, although there was a trend for stem water potential to be highest with 3309C and lowest with 5C. The rootstock effect on yield formation depended on the scion cultivar, and variations in different yield components often cancelled out each other, but 3309C (Merlot and Syrah), 5C (Merlot and Chardonnay), and own roots (Chardonnay) were often associated with high yields. Nevertheless, the rootstocks had only minor effects on fruit ripening and did not consistently alter soluble solids, TA, $\mathrm{K}^{+}$, or anthocyanin pigments, but the $\mathrm{pH}$ was higher in fruit from own-rooted vines compared with grafted Merlot and Chardonnay. Overall, scion effects and differences due to yearly climate variation far outweighed any differences due to rootstock.
\end{abstract}

Key words: cultivar, fruit composition, fruit set, grape berry, growth, rootstock, vigor, Vitis vinifera, yield components

Crosses of diverse North American Vitis species are used as rootstocks in the majority of vineyards throughout the world as the sole feasible means to prevent vineyard decline due to infestation of susceptible European winegrapes (Vitis vinifera L.) by phylloxera (Daktulosphaira vitifoliae Fitch). Rootstocks are also used for their resistance to or tolerance of nematodes, adverse soil conditions such as drought, waterlogging, high or low $\mathrm{pH}$, or salinity, and their ability to influence vine vigor and fruit ripening (Currle et al. 1983, Pongrácz 1983, Galet 1998, Whiting 2004). Although the compounds responsible for fruit composition are mostly determined by the genotype of the scion (e.g., Gholami et al. 1995), rootstocks may alter fruit composition indirectly by influencing scion vigor, canopy configuration, yield formation, and nutrient uptake (Schumann 1974, Ruhl et al. 1988, Keller et al. 2001a, 2001b).

${ }^{1}$ Professor of Viticulture, ${ }^{2}$ Research Technology Supervisor, Department of Horticulture and Landscape Architecture, and ${ }^{3}$ Associate Professor of Enology, School of Food Science, Irrigated Agriculture Research and Extension Center, Washington State University, 24106 N. Bunn Road, Prosser, WA 99350. *Corresponding author (email: mkeller@wsu.edu; fax: 509 786-9370)

Acknowledgments: This work was funded by WSU's Agricultural Research Center, project WNP00673, and by the Washington Wine Advisory Committee program. Plant material was donated by Ste. Michelle Wine Estates and Inland Desert Nursery. Trellis materials were donated by Quiedan Company. The authors thank R.L. Wample for initiation of the project and A. Kawakami, C. Longoria, M. Mireles, and E. Harwood for technical assistance.

Manuscript submitted Aug 2011, revised Oct 2011, accepted Oct 2011

Copyright (C) 2012 by the American Society for Enology and Viticulture. All rights reserved.

doi: 10.5344/ajev.2011.11078
Despite the presence of phylloxera in the region and unlike most of the world's grapegrowing areas, the vast majority of vineyards in eastern Washington State are planted to vines on their own roots. Vineyards in this arid region $(<300 \mathrm{~mm}$ annual precipitation) are typically drip-irrigated using deficitirrigation strategies, which are used as a tool to control canopy development and fruit ripening (Wample and Smithyman 2000, Keller et al. 2008). The main reason for growers' reluctance to adopt rootstocks as a cultural practice is the periodic occurrence of very cold winter temperatures leading to cold injury in grapevines. This is of particular economic concern for grafted vines (Folwell et al. 2001), which cannot simply be retrained from suckers following lethal cold injury to the trunk. Although the ability of Washington's wine industry to remain competitive is dependent upon the consistent production of high-quality fruit to make high-quality wines, there is no local experience with the performance of grafted vines. This lack of familiarity may leave the industry vulnerable to the inadvertent spread of phylloxera, however unlikely such a scenario may seem. To address this issue, a task force was assembled in 1992 that recommended that Washington State University begin a research program to evaluate rootstock adaptability to and performance under local climatic and edaphic conditions. The rootstocks $V$. berlandieri $\times V$. riparia Teleki 5C (5C), $V$. berlandieri $\times V$. rupestris 99 Richter (99R), 140 Ruggeri (140Ru), 1103 Paulsen (1103P), V. riparia $\times V$. rupestris 3309 Couderc (3309C), and an unnamed rootstock selection from Cornell University were chosen for evaluation.

A rootstock field trial was planted in 1999, and evaluation of scion performance began in 2002. In addition to the six rootstocks, the three $V$. vinifera cultivars that were used as scions (Merlot, Syrah, Chardonnay) were also planted on their 
own roots to permit comparison of vines grafted to rootstocks with own-rooted vines that remain the industry standard. The purpose here is to describe rootstock effects and scion $\times$ rootstock interactions on scion growth, yield formation, sourcesink relations, and fruit ripening under conditions of deficit irrigation. A companion study evaluated rootstock effects on fruit and wine composition. The findings of that study are reported in a separate publication (Harbertson and Keller 2012).

\section{Materials and Methods}

Vineyard site, plant material, and management. The experiment was conducted in a vineyard at the Irrigated Agriculture Research and Extension Center near Prosser, WA (4617'40”N; 11944'37'W; elevation $365 \mathrm{~m}$ ), from 2007 through 2009. Vines were planted with $1.83 \mathrm{~m}$ between vines in north-south-oriented rows spaced $2.74 \mathrm{~m}$ apart on a $2 \%$ south-facing slope. The soil is a well-drained, uniformly deep ( $>1 \mathrm{~m}$ ) Shano silt loam, $\mathrm{pH} 8.0$, with $0.25 \%$ organic matter and an estimated soil water content $\left(\theta_{\mathrm{v}}\right)$ of $\sim 25 \%(\mathrm{v} / \mathrm{v})$ at field capacity and $\sim 8 \%$ at permanent wilting point (vineyard 4 in Davenport et al. 2008). Merlot, Syrah, and Chardonnay were evaluated on their own roots $(\mathrm{OR})$ or grafted to $5 \mathrm{C}$, 99R, 140Ru, 1103P, 3309C, and an unnamed rootstock received from Cornell University. Rootstocks were propagated by aseptic shoot-tip culture to eliminate crown gall bacteria (Agrobacterium vitis), planted in an increase block in 1998, and their identity was confirmed by DNA typing (Foundation Plant Services, UC Davis, CA). Although the selection from Cornell University was initially identified as $V$. rupestris $\times V$. riparia 101-14 Millardet and de Grasset (101-14 Mgt), subsequent evaluation revealed that it was not 101-14 Mgt nor any other commercially available rootstock, but a likely sibling or seedling of 101-14 Mgt (hereafter termed 101CU; P. Cousins and M.A. Walker, personal communication, 2010). Rooted dormant cuttings were planted in 1999 and grafted with certified nursery material by chip-budding in 2002. Cold injury due to unseasonably low temperatures in late October of both 2002 and 2003 necessitated regrafting of many vines in 2003 and 2004 (Keller et al. 2007). The vines were trained to two trunks and bilateral cordons at a height of $95 \mathrm{~cm}$ and winter-pruned to two-bud spurs, leaving 25 buds (excluding basal buds) per vine. Shoots were loosely positioned between two pair of foliage wires placed $35 \mathrm{~cm}(25 \mathrm{~cm}$ apart $)$ and 70 $\mathrm{cm}$ (5 cm apart) above the cordon. No shoot thinning, hedging, or other canopy management practices were applied to permit full expression of potential rootstock effects.

The vineyard was drip-irrigated using pressure-compensated emitters with a flow rate of $2 \mathrm{~L} / \mathrm{hr}$, spaced $90 \mathrm{~cm}$ apart. Irrigation was applied if necessary between budbreak and bloom to avoid plant water stress, then water was withheld through mid-July to achieve control of shoot growth, after which irrigation was applied approximately once weekly through summer and less frequently during the cooler ripening period. The initial goal for the fruit set to veraison period was to maintain a target $\theta_{\mathrm{v}} \approx 11 \%$ (averaged over the top 90 $\mathrm{cm}$, for measurement see below) for Chardonnay and Merlot and $10 \%$ for Syrah because of the more vigorous shoot growth of the latter. Given the very low vigor at this site, the target $\theta_{v}$ was increased to $11-12 \%$ in 2008 and to $13-14 \%$ in 2009 . The amount of irrigation water (IW in $\mathrm{mm}$ ) to be applied for each irrigation set was calculated from measured $\theta_{v}$ (converted to $\mathrm{mm})$, rainfall $(\mathrm{RF})$, and crop evapotranspiration $\left(\mathrm{ET}_{\mathrm{c}}\right)$ : $\mathrm{IW}=$ target $\theta_{\mathrm{v}}-$ measured $\theta_{\mathrm{v}}-\mathrm{RF}+\mathrm{ET}_{\mathrm{c}}$. In addition, $\mathrm{ET}_{\mathrm{c}}=0.8 \times$ $\mathrm{K}_{\mathrm{c}} \times \mathrm{ET}_{0}$, where $\mathrm{K}_{\mathrm{c}}$ was the published $V$. vinifera crop coefficient (Evans et al. 1993) for appropriate cumulative growing degree days (GDD, see below) and $\mathrm{ET}_{0}$ was the pan (grass) evapotranspiration for the preceding irrigation interval. Following irrigation near veraison and during early ripening, the soil was again permitted to dry down to encourage cold acclimation. After harvest, irrigation was applied to replenish $\theta_{v} \geq 18 \%$ to minimize cold injury to roots in winter.

Nitrogen fertilizer $\left(\mathrm{NH}_{4} \mathrm{NO}_{3} \times\left(\mathrm{NH}_{2}\right)_{2} \mathrm{CO}\right)$ was applied annually at a rate of $\sim 20 \mathrm{~kg} \mathrm{~N} / \mathrm{ha}$ by fertigation; the rate was split between the six-leaf and bloom stages. Because some vines showed symptoms of potassium deficiency in 2008, potassium fertilizer $\left(\mathrm{K}_{2} \mathrm{SO}_{4} \times 2 \mathrm{MgSO}_{4}\right)$ was shanked $\sim 10 \mathrm{~cm}$ into the soil on both sides of each vine row after harvest of 2008 and 2009 at a rate of $\sim 170 \mathrm{~kg} \mathrm{~K} / \mathrm{ha}$. Vineyard floor management consisted of mowing a permanent cover crop and a 120 $\mathrm{cm}$ under-vine herbicide strip.

Measurements. Meteorological conditions were monitored using daily raw data derived from a Washington State University AgWeatherNet weather station that has been in operation since 1989 and is located at the same elevation $<1 \mathrm{~km}$ to the east of the trial site. Growing-season heat units were estimated as GDD $>10^{\circ} \mathrm{C}$ accumulated from 1 Apr through 31 Oct, using daily mean temperatures calculated from daily maximum $\left(\mathrm{T}_{\max }\right)$ and minimum temperatures $\left(\mathrm{T}_{\min }\right)$. Neutron probes (503 DR Hydroprobe; CPN International, Concord, CA) were used to monitor $\theta_{v^{\prime}}$. One (2007 and 2008) or two (2009) PVC probe-access tubes were installed in each scion/ rootstock combination to a soil depth of $1 \mathrm{~m}$ beneath the drip line and equidistant between drip emitters. In addition, stem water potential (i.e., petiole xylem pressure, $\Psi_{\mathrm{x}}$ ) was measured using a pressure chamber (PMS Instrument Co., Albany, OR) on at least four leaves per treatment replicate. Fully expanded, sun-exposed leaves were measured after they had been enclosed in aluminum-coated plastic bags for $>30 \mathrm{~min}$ between 11:00 and 15:00 LST. Measurements were conducted four times before and once after veraison in 2007, four times each before and after veraison in 2008, and weekly from fruit set through harvest in 2009.

Vine phenology was monitored at least weekly. Flowers per cluster and percent fruit set were estimated by counting abscised flower caps collected in gauze bags $(1 \mathrm{~mm}$ perforations) and counting the berries of the same clusters (Keller et al. 2010). Average flower size for each cluster was estimated by drying $\left(60^{\circ} \mathrm{C}\right)$ and weighing the collected flower caps, assuming that cap weight is proportional to flower weight and, hence, size (Keller et al. 2010). Yield, clusters per vine, and mean berry weight were determined at harvest and used to estimate clusters per shoot and berries per cluster. Pruning weights were recorded during winter pruning, and canes were counted at the same time. 
Fruit ripening was assessed by biweekly sampling beginning during the lag phase of berry growth. Five berries were plucked from each of five clusters per replicate, alternately from the top, middle, and bottom of each cluster, and kept in a zip-lock bag on ice. At harvest, which occurred on the same day for all rootstocks within a scion cultivar, 100 berries were collected per replicate. Berry samples were weighed and analyzed the following day for total soluble solids (TSS), titratable acidity (TA), $\mathrm{pH}$, and anthocyanin color (Harbertson and Keller 2012). Juice potassium concentration ([K+ $\left.\mathrm{K}^{+}\right)$was measured in 2007 and 2009 harvest samples as described by Harbertson and Harwood (2009). Additional fruit composition data and winemaking procedures and results are reported in a companion paper (Harbertson and Keller 2012).

Experimental design and data analysis. The experiment was designed as a split-plot with each of the three cultivars randomly assigned to both of two adjacent 15 -row blocks and the seven rootstocks (one own-rooted and six grafted treatments) assigned to five subplots within each cultivar main plot. Each cultivar plot consisted of five rows (60 vines/row), and each rootstock was replicated once (7 vines/rootstock) in each row. There were five or six own-rooted buffer vines at either end of the row and five buffer rows on either side of the experimental unit. All measurements were taken on three interior vines (data vines), flanked by two buffer vines of the same rootstock on either side of each of the $10 \mathrm{scion} /$ rootstock replicates. Vegetative and yield component data were collected separately for each data vine. Fruit set was estimated on both clusters of one two-cluster shoot on one vine of five scion/rootstock replicates. Fruit composition data were collected as composite samples from the data vines of each replicate.

All data were analyzed using Statistica (version 10; StatSoft, Tulsa, OK). Results were first analyzed as a split-splitplot design using four-way (year $\times$ block $\times$ cultivar $\times$ rootstock) analysis of variance (ANOVA) and F-test. Because the block effect was almost never significant and cultivar $\times$ rootstock interactions were almost always significant, data were next subjected to three-way (year $\times$ cultivar $\times$ rootstock) ANOVA. Three-way interactions were almost never significant, but year and cultivar effects and year $\times$ cultivar interactions were almost always significant and often failed Levene's test due to differences in variance among years. Therefore, data were also analyzed by two-way ANOVA using the general linear model procedure. This analysis was performed by cultivar (year $\times$ rootstock) to test for consistency of rootstock effects within cultivars over time and by year (cultivar $\times$ rootstock) to test for consistency of rootstock effects across cultivars. Duncan's new multiple range test was used for posthoc comparison of significant treatment means, and orthogonal contrasts were used to compare own-rooted vines with grafted vines for each cultivar. The $\theta_{\mathrm{v}}, \Psi_{\mathrm{x}}$, berry weight, and fruit composition data were analyzed with a repeated measures design. Individual $\mathrm{pH}$ values were converted to $\left[\mathrm{H}^{+}\right]$for statistical analysis, and the reported means were recalculated from means of $\left[\mathrm{H}^{+}\right]$. Correlation analysis was used to compare relationships between selected pairs of variables.

\section{Results}

Weather, soil moisture, and vine water status. Among the three growing seasons, 2007 and 2008 were below and 2009 was above the 22-year average in terms of heat accumulation from 1 Apr through 31 Oct (Figure 1). Mean $\mathrm{T}_{\max } /$ $\mathrm{T}_{\text {min }}$ between budbreak (phenological stages were averaged for the three cultivars) and bloom was similar among years, varying only from $22.3 / 7.4^{\circ} \mathrm{C}$ (2007) to $22.8 / 7.9^{\circ} \mathrm{C}$ (2009). The $\mathrm{T}_{\max } / \mathrm{T}_{\min }$ range during bloom-fruit set was more pronounced: $23.1 / 8.3^{\circ} \mathrm{C}(2007)$ to $26.8 / 10.2^{\circ} \mathrm{C}(2008)$. The variation of $29.3 / 13.5^{\circ} \mathrm{C}(2007)$ to $30.1 / 13.0^{\circ} \mathrm{C}(2009)$ was again low between fruit set and veraison but significant from veraison to harvest, ranging from $22.4 / 9.0^{\circ} \mathrm{C}(2008)$ to $27.3 / 10.9^{\circ} \mathrm{C}$ (2009). While 2007 and 2008 had similar numbers of hot $\left(\mathrm{T}_{\max }\right.$ $\left.>30^{\circ} \mathrm{C}\right)$ and very hot $\left(\mathrm{T}_{\max }>35^{\circ} \mathrm{C}\right)$ days during the growing season, 2009 had considerably more hot and very hot days, most of which occurred between fruit set and veraison (Table 1). 2008 had the most cool $\left(\mathrm{T}_{\max }<15^{\circ} \mathrm{C}\right)$ and very cool ( $\mathrm{T}_{\max }$ $<10^{\circ} \mathrm{C}$ ) days in spring, and 2009 had several very cool days in fall. The first fall frost occurred between $1 \mathrm{~d}$ before (2009) and $16 \mathrm{~d}$ after (2007) the harvest of Syrah, which was always the last cultivar to be harvested. Precipitation was below average in all three years, and there was very little rainfall during the growing season (Table 1).

At budbreak, $\theta_{\mathrm{v}}$ of the top $90 \mathrm{~cm}$ of soil varied from considerably below (2007: $17.5 \% \mathrm{v} / \mathrm{v} ; 2008: 18.9 \%$ ) to slightly below (2009: 22.6\%) field capacity. Because of minimal rainfall, the subsequent $\theta_{v}$ pattern mostly reflected the seasonal irrigation strategy. In 2007 the soil began to dry down immediately after budbreak, whereas in 2008 and 2009 more frequent irrigation kept $\theta_{v}$ high through fruit set (Figure 2). In all years, $\theta_{\mathrm{v}}$ reached a temporary minimum before veraison, but $\theta_{\mathrm{v}}$ was lower $(p<0.001)$ throughout the 2007 growing season than in the other two years except for a strong temporary increase due to irrigation at veraison. Each year, and as intended by the irrigation strategy, the soil under Syrah was usually $\leq 1 \%$ (v/v) drier than that under Merlot and Chardonnay $(p<0.05)$. Across the three scion cultivars, 1103P was

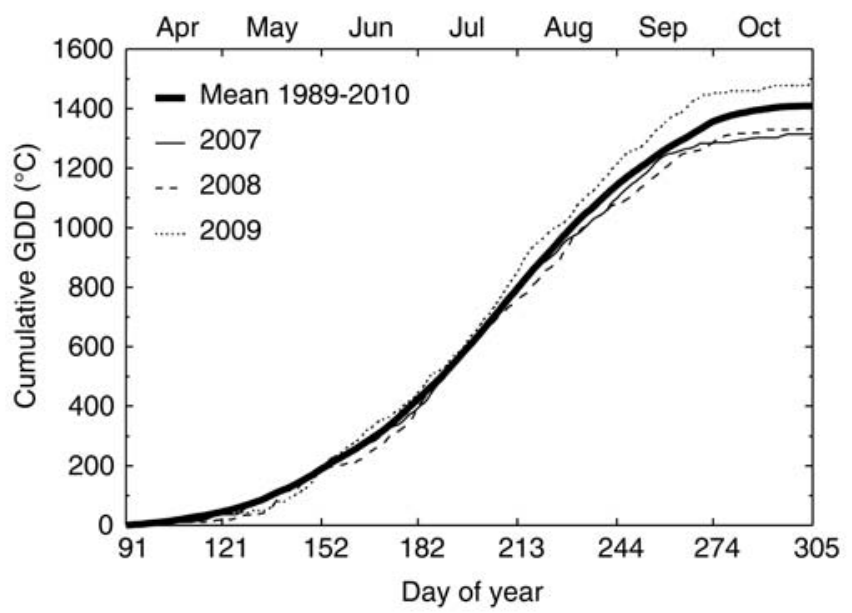

Figure 1 Growing degree day accumulation (base $10^{\circ} \mathrm{C}$ ) in Prosser, WA, from 1 Apr to 31 Oct 2007 through 2009. 
the rootstock that was associated with the lowest $\theta_{\mathrm{v}}$, which was on average $\sim 1.2 \%(\mathrm{v} / \mathrm{v})$ lower than with other rootstocks and own-rooted vines ( $p<0.01$, data not shown). The only other significant rootstock effect was the trend in 2009 toward slightly elevated $\theta_{\mathrm{v}}$ with $140 \mathrm{Ru}(p<0.01)$. Each year, however, the spatial variation in $\theta_{\mathrm{v}}$ due to varying soil properties across the vineyard block was usually greater than that due to either scion or rootstock cultivar.

In 2008 and 2009, but not in 2007, there were significant positive correlations between $\theta_{v}$ and $\Psi_{x}$ for all three scion cultivars; the strength of the relationship varied among cultivars as well as between years $(0.36<\mathrm{r}<0.82, p<0.05)$. When the $\Psi_{x}$ data were averaged for the pre- or postveraison berry development phases, there were few and inconsistent differences among scion cultivars (Table 2) and none among rootstocks (data not shown). Seasonal trends and mean values of $\Psi_{x}$ were rather similar among scion cultivars in 2007, but Syrah maintained somewhat higher $\Psi_{\mathrm{x}}$ after veraison in 2008 than did the other cultivars (Table 2). In 2009 Chardonnay sustained the highest $\Psi_{\mathrm{x}}$ after veraison. Evaluating individual measurement dates uncovered a few significant but small differences among rootstocks (data not shown). All three cultivars maintained the highest midday $\Psi_{\mathrm{x}}$ on $3309 \mathrm{C}$ throughout most of the 2007 growing season $(p<0.05)$. In 2008, vines (especially Syrah) grafted to $5 \mathrm{C}$ had a lower $\Psi_{\mathrm{x}}$ compared with other rootstocks $(p<0.05)$. In 2009, 3309C (along with $140 \mathrm{Ru}$ ) again led to the highest $\Psi_{\mathrm{x}}$, while $5 \mathrm{C}$ and $101 \mathrm{CU}$ were associated with the lowest $\Psi_{\mathrm{x}}(p<0.001)$. Own-rooted vines did not differ from grafted vines in any cultivar or year.

Vine growth. One of the rootstocks, 99R, was eliminated from the evaluation because both the rootstock itself and the scions grafted to it often died back during the winter

Table 2 Effect of scion cultivar on average midday stem water potential $\left(\Psi_{x}\right)$ during fruit ripening of field-grown grapevines in the Yakima Valley, WA (all SE $\leq 0.05 \mathrm{MPa}$ ).

\begin{tabular}{lccc}
\hline & \multicolumn{3}{c}{$\Psi_{\mathbf{x}}(\mathbf{M P a})$} \\
\cline { 2 - 4 } Scion & $\mathbf{2 0 0 7}$ & $\mathbf{2 0 0 8}$ & $\mathbf{2 0 0 9}$ \\
\hline Merlot & $-0.83 \mathrm{~b}^{\mathrm{b}}$ & $-1.18 \mathrm{~b}$ & $-1.26 \mathrm{~b}$ \\
Syrah & $-0.71 \mathrm{a}$ & $-0.99 \mathrm{a}$ & $-1.30 \mathrm{~b}$ \\
Chardonnay & $-0.77 \mathrm{ab}$ & $-1.17 \mathrm{~b}$ & $-1.01 \mathrm{a}$ \\
Signfa & 0.070 & 0.012 & $<0.001$
\end{tabular}

aSignificance ( $p$ value) of cultivar effect. Preveraison means were similar for all cultivars (average $-0.81 \mathrm{MPa}$ in $2007 ;-0.84 \mathrm{MPa}$ in 2008; -1.01 MPa in 2009).

${ }^{b}$ Means within columns followed by different letters differ significantly at $p<0.05$ by Duncan's new multiple range test.

Table 1 Meteorological data from the Washington State University AgWeatherNet Roza weather station near Prosser, WA $(<1 \mathrm{~km}$ east of vineyard site).

\begin{tabular}{|c|c|c|c|c|c|c|c|}
\hline \multirow[b]{2}{*}{ Year } & \multirow[b]{2}{*}{$\operatorname{GDD}\left({ }^{\circ} \mathrm{C}\right)^{\mathrm{a}}$} & \multicolumn{4}{|c|}{ Seasonal temperature $(\mathrm{d})^{\mathrm{b}}$} & \multicolumn{2}{|c|}{ Precipitation $(\mathrm{mm})$} \\
\hline & & $>30^{\circ} \mathrm{C} \mathrm{PV/RP}$ & $>35^{\circ} \mathrm{C}$ PV/RP & $<15^{\circ} \mathrm{C} \mathrm{S} / \mathrm{F}$ & $<10^{\circ} \mathrm{C} \mathrm{S} / \mathrm{F}$ & Annual & Seasonal $^{\mathrm{a}}$ \\
\hline 2007 & 1314 & $26 / 8$ & $1 / 0$ & $16 / 19$ & $0 / 0$ & 152 & 70 \\
\hline 2008 & 1333 & $30 / 3$ & $5 / 0$ & $23 / 13$ & $6 / 0$ & 117 & 45 \\
\hline 2009 & 1481 & $33 / 14$ & $11 / 2$ & $14 / 12$ & $2 / 6$ & 135 & 64 \\
\hline 1989-2010 & 1409 & 38 & 7 & $13 / 11$ & $1 / 2$ & 227 & 111 \\
\hline
\end{tabular}

aCumulative growing degree days $\left(>10^{\circ} \mathrm{C}\right)$ and rainfall from $1 \mathrm{Apr}$ to 31 Oct.

${ }^{\mathrm{b} N u m b e r}$ of days from $1 \mathrm{Apr}$ to 31 Oct with maximum temperatures greater or lower than four threshold temperatures (PV: preveraison/RP: ripening; S: spring/F: fall).
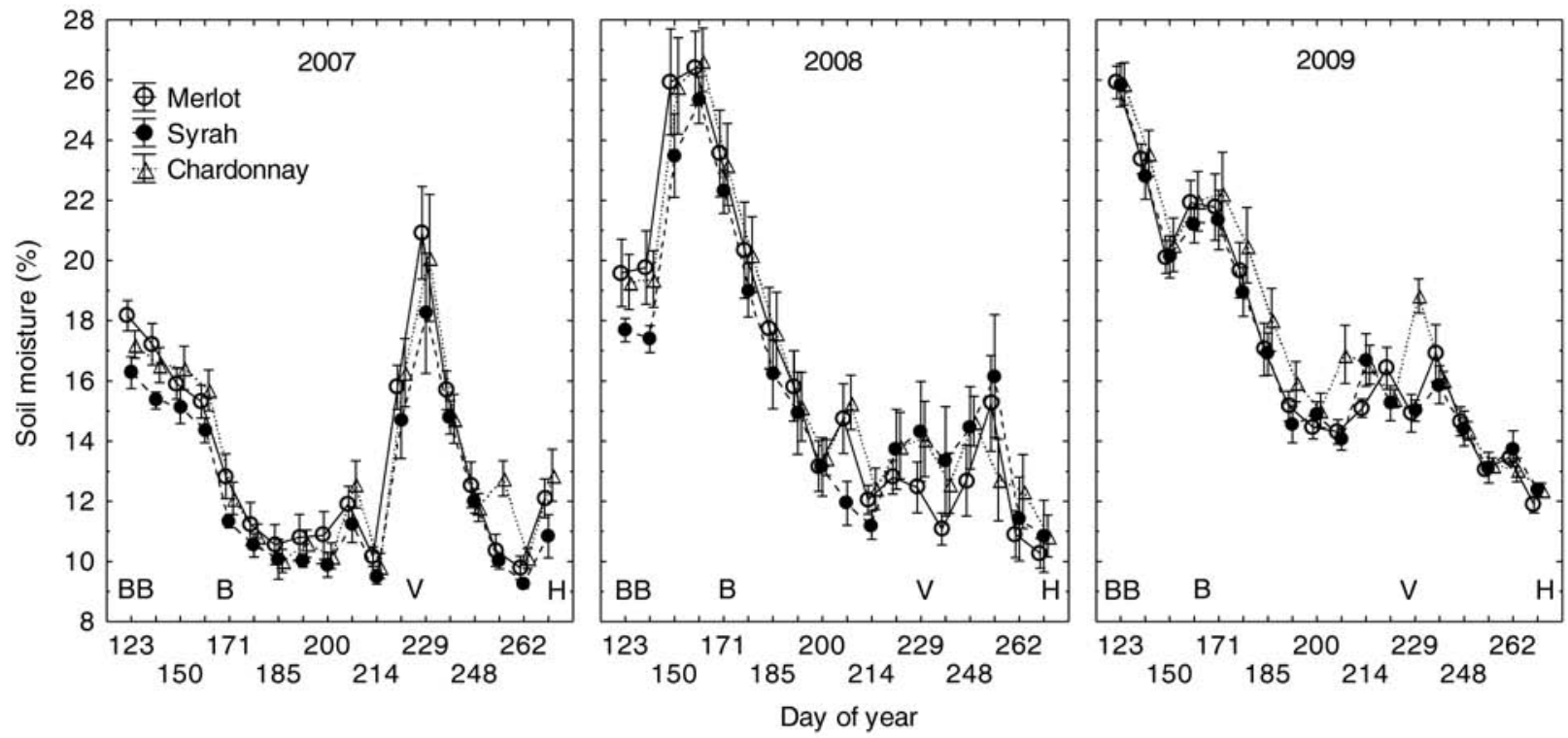

Figure 2 Influence of growing season and scion cultivar on the volumetric soil water content in the top $90 \mathrm{~cm}$ (means $\pm S E$ ) of a deficit-irrigated rootstock trial block in Prosser, WA, in $2007(n=5), 2008(n=5)$, and $2009(n=10$; BB: budbreak, B: bloom, V: veraison, H: harvest). 
following grafting. Those vines that survived the first two years after grafting have had no further problems with winter survival, probably because once established, the woody rootstocks and grafts no longer suffered from the late maturation that characterized their green shoots. Among the remaining rootstocks (including own-rooted vines) there was no consistent effect on scion phenology in any cultivar (data not shown). However, own-rooted Merlot and Chardonnay had a greater capacity for growth than did grafted vines. Across the three years and despite efforts to prune to similar bud numbers, these cultivars grew on average $52 \%$ more shoots $(21 / \mathrm{m})$ on their own roots than when they were grafted $(14 / \mathrm{m}$; Table 3). Merlot and Chardonnay grafted to $5 \mathrm{C}$ and $101 \mathrm{CU}$ usually grew intermediate shoot numbers. These differences decreased from 2007 to 2009 as the vines matured. No such rootstock effect was observed with Syrah as the grafting partner; all combinations grew $\sim 15$ shoots/m of canopy (Table 3 ).

Table 3 Effect of rootstock on measures of vine vigor and balance of three scion cultivars in the Yakima Valley, WA, over three years.

\begin{tabular}{|c|c|c|c|c|}
\hline & $\begin{array}{c}\text { Pruning wt } \\
(\mathrm{g} / \mathrm{m})\end{array}$ & $\begin{array}{l}\text { Cane no. } \\
\text { (canes } / \mathrm{m})\end{array}$ & $\begin{array}{c}\text { Cane wt } \\
(\mathrm{g})\end{array}$ & $\begin{array}{c}\text { Yield: } \\
\text { pruning wt }\end{array}$ \\
\hline \multicolumn{5}{|l|}{ Merlot } \\
\hline Own roots & $246 a^{b}$ & $20 \mathrm{a}$ & $12.8 \mathrm{C}$ & $10.1 \mathrm{~d}$ \\
\hline $5 \mathrm{C}$ & $254 \mathrm{a}$ & $16 \mathrm{~b}$ & $16.8 \mathrm{a}$ & $13.0 \mathrm{bc}$ \\
\hline 140Ru & $177 \mathrm{~b}$ & $13 \mathrm{c}$ & $13.7 \mathrm{c}$ & $15.0 \mathrm{ab}$ \\
\hline $1103 \mathrm{P}$ & $184 \mathrm{~b}$ & $14 \mathrm{C}$ & $13.9 \mathrm{bc}$ & $12.4 \mathrm{~cd}$ \\
\hline $3309 C$ & $230 \mathrm{a}$ & $15 \mathrm{bc}$ & $15.7 \mathrm{ab}$ & $16.0 \mathrm{a}$ \\
\hline $101 \mathrm{CU}$ & 253 a & $16 \mathrm{~b}$ & $15.9 a b$ & $10.4 \mathrm{~cd}$ \\
\hline 2007 & 218 & $19 a$ & $11.8 \mathrm{c}$ & $7.0 \mathrm{c}$ \\
\hline 2008 & 236 & $13 \mathrm{~b}$ & $17.6 \mathrm{a}$ & $17.2 \mathrm{a}$ \\
\hline 2009 & 219 & $14 \mathrm{~b}$ & $15.0 \mathrm{~b}$ & $13.2 \mathrm{~b}$ \\
\hline \multicolumn{5}{|l|}{ Syrah } \\
\hline Own roots & 301 bc & $16 a b$ & $19.9 a b$ & $7.3 \mathrm{~d}$ \\
\hline $5 \mathrm{C}$ & $351 a b$ & $17 \mathrm{a}$ & $19.8 a b$ & $8.9 \mathrm{~cd}$ \\
\hline 140Ru & 306 bc & $14 \mathrm{~b}$ & $19.3 a b$ & $14.2 \mathrm{ab}$ \\
\hline $1103 \mathrm{P}$ & $246 c$ & $16 a b$ & $15.1 \mathrm{c}$ & $11.0 \mathrm{bc}$ \\
\hline $3309 C$ & 393 a & $17 a b$ & $21.4 \mathrm{a}$ & $14.5 \mathrm{a}$ \\
\hline $101 \mathrm{CU}$ & 306 bc & $16 a b$ & $18.0 \mathrm{bc}$ & $11.3 \mathrm{abc}$ \\
\hline 2007 & 288 & 18 & 17.2 b & $6.7 \mathrm{c}$ \\
\hline 2008 & 322 & 15 & $20.1 \mathrm{a}$ & $15.5 \mathrm{a}$ \\
\hline 2009 & 335 & 15 & $19.4 \mathrm{a}$ & $10.4 \mathrm{~b}$ \\
\hline \multicolumn{5}{|l|}{ Chardonnay } \\
\hline Own roots & 442 a & $23 \mathrm{a}$ & $20.3 a b$ & $7.3 \mathrm{c}$ \\
\hline $5 \mathrm{C}$ & $390 a b$ & $17 \mathrm{~b}$ & $22.6 \mathrm{a}$ & $9.0 \mathrm{bc}$ \\
\hline $140 R u$ & $211 c$ & $13 d$ & $16.1 \mathrm{bcd}$ & $16.9 \mathrm{a}$ \\
\hline $1103 P$ & $233 \mathrm{c}$ & $15 \mathrm{~cd}$ & $15.3 \mathrm{~cd}$ & $10.7 \mathrm{~b}$ \\
\hline $3309 \mathrm{C}$ & $195 \mathrm{c}$ & $14 d$ & $14.0 \mathrm{~d}$ & $16.0 \mathrm{a}$ \\
\hline $101 \mathrm{CU}$ & $326 \mathrm{~b}$ & $16 \mathrm{bc}$ & $19.1 \mathrm{abc}$ & 9.2 bc \\
\hline 2007 & $245 b$ & $22 \mathrm{a}$ & $11.1 \mathrm{~b}$ & 8.9 b \\
\hline 2008 & $321 \mathrm{a}$ & $13 \mathrm{~b}$ & $20.7 \mathrm{a}$ & $12.9 \mathrm{a}$ \\
\hline 2009 & $340 \mathrm{a}$ & $14 \mathrm{~b}$ & $21.9 \mathrm{a}$ & $11.1 \mathrm{a}$ \\
\hline \multicolumn{5}{|l|}{ Signf $^{a}$} \\
\hline $\mathrm{S} \times \mathrm{R}$ & $<0.001$ & $<0.001$ & $<0.001$ & 0.195 \\
\hline$Y \times S$ & 0.053 & $<0.001$ & $<0.001$ & $<0.001$ \\
\hline$Y \times R$ & 0.017 & 0.301 & 0.097 & 0.031 \\
\hline
\end{tabular}

a Significance ( $p$ value) of scion $(S) \times$ rootstock $(R)$, year $(Y) \times S$, and $\mathrm{Y} \times \mathrm{R}$ interactions.

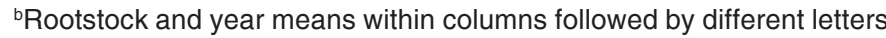
differ significantly at $p<0.05$ by Duncan's new multiple range test.
Shoot numbers varied more than 10 -fold but were strongly correlated between years in all scion/rootstock combinations $(0.77<\mathrm{r}<0.81, p<0.001)$, indicating that the spatial variation within this vineyard was dominant over the temporal variation. While shoot number may be taken as a measure of vine capacity, average cane weight at pruning is a better indicator of shoot vigor. These two variables are usually inversely related (i.e., vines that grow more shoots grow less vigorously), but in this study there was no consistent association between shoot number and cane weight. Cane weights were lowest after the 2007 growing season and similar in the other two years (Table 3). Syrah had heavier canes than Merlot and Chardonnay in 2007, and Merlot had lighter canes than the other cultivars in 2008 and $2009(p<0.001)$. Merlot produced heavier canes on $5 \mathrm{C}, 101 \mathrm{CU}$, and $3309 \mathrm{C}$ than on the other rootstocks or own roots, whereas 1103P led to lower cane weights compared with other rootstocks in Syrah. Chardonnay canes were heaviest in own-rooted vines, $5 \mathrm{C}$, and $101 C U$. In all three cultivars, the variation in pruning weight was somewhat more closely associated with differences in cane weight $(0.60<\mathrm{r}<0.86, p<0.001)$ than with differences in cane number $(0.46<\mathrm{r}<0.69, p<0.001)$.

In all scion cultivars and rootstocks, pruning weight was positively correlated with the previous winter's pruning weight. The contribution of the variation in pruning weight in one year to that in the following year increased from 2007 to $2009: \mathrm{r}=0.50 \rightarrow 0.70$ for Merlot; $\mathrm{r}=0.55 \rightarrow 0.83$ for Syrah; and $\mathrm{r}=0.54 \rightarrow 0.87$ for Chardonnay (all $p<0.001$ ). These results show that larger vines remained larger over time and that within-vineyard variation changed little from year to year. Merlot consistently had the lowest pruning weights, and Syrah had the highest pruning weights in 2007 but was similar to Chardonnay in 2008 and 2009 (Table 3). While Merlot pruning weights did not exceed $0.7 \mathrm{~kg} / \mathrm{m}$ of canopy, some Syrah and Chardonnay vines reached pruning weights of up to 1.6 $\mathrm{kg} / \mathrm{m}$. However, the mean $( \pm \mathrm{SE})$ pruning weight varied only from $0.22 \pm 0.01$ to $0.34 \pm 0.02 \mathrm{~kg} / \mathrm{m}$ across scion cultivars and years. The rootstock effect was significant in 2008 and 2009, which resulted in a significant year $\times$ rootstock interaction (Table 3). Because the scion $\times$ rootstock interaction was also significant, the rootstock effect was analyzed separately for each cultivar. In Merlot, 140Ru and 1103P decreased pruning weights by $27 \%$ compared with other rootstocks and ownrooted vines (Table 3). Syrah had the lowest pruning weights when grafted to $1103 \mathrm{P}$ and the highest on 3309C. Chardonnay pruning weights were $49 \%$ lower with $3309 \mathrm{C}$, $140 \mathrm{Ru}$, and $1103 \mathrm{P}$ compared with 5C and own-rooted vines.

Yield formation and vine balance. A vine's yield potential at the beginning of a growing season may be estimated from the number of clusters per vine (shoots/vine $\times$ clusters/ shoot) and the average number of flowers per cluster (inflorescence size). Annual variation dominated the total variation in cluster numbers. Despite higher shoot numbers, there were generally fewer clusters per vine in 2007 than in 2008 and 2009 , with a range among means of 1.6-fold in Merlot, 1.8fold in Syrah, and 1.3-fold in Chardonnay (Table 4). There was a significant year $\times$ rootstock interaction across but not 
within scion cultivars, indicating that the rootstock effect on cluster numbers of each scion was relatively consistent over time. Merlot produced fewer clusters when grafted to 1103P and $140 \mathrm{Ru}$ compared with other rootstocks and own-rooted vines, Syrah was most productive on 3309C, and Chardonnay produced the fewest clusters on $140 \mathrm{Ru}$ and the most on its own roots (Table 4). Merlot had the fewest flowers per cluster in 2007 and the most in 2008, while inflorescence size varied little from year to year in Syrah and Chardonnay (Table 5). Chardonnay had the largest flowers, followed by Syrah and finally Merlot $(p<0.001)$. Across scion cultivars, flowers were $23 \%$ smaller in 2007 than in 2008 and 2009 (Table 5), and 1103P was often associated with smaller flowers compared with other rootstocks and own-rooted vines ( $p$ $<0.01$ ). Whereas there was no significant rootstock effect on Merlot and Chardonnay inflorescence size, Syrah tended to produce more flowers per inflorescence on $5 \mathrm{C}$ and $101 \mathrm{CU}$ than on its own roots $(p<0.05)$. Merlot had more flowers per

Table 4 Effect of rootstock on yield and its components of three scion cultivars in the Yakima Valley, WA, over three years.

\begin{tabular}{|c|c|c|c|c|c|}
\hline & $\begin{array}{c}\text { Yield }^{\mathrm{b}} \\
\text { (kg/vine) }\end{array}$ & $\begin{array}{c}\text { Clusters } \\
\text { /vine }\end{array}$ & $\begin{array}{c}\text { Cluster } \\
\text { wt (g) }\end{array}$ & $\begin{array}{l}\text { Berries } \\
\text { /cluster }\end{array}$ & $\begin{array}{l}\text { Berry } \\
\text { wt (g) }\end{array}$ \\
\hline \multicolumn{6}{|l|}{ Merlot } \\
\hline Own roots & $4.50 b^{c}$ & $73 \mathrm{a}$ & $57 \mathrm{c}$ & $57 \mathrm{c}$ & $0.98 \mathrm{c}$ \\
\hline $5 \mathrm{C}$ & $5.26 \mathrm{ab}$ & $69 \mathrm{a}$ & $74 \mathrm{a}$ & $71 \mathrm{a}$ & $1.06 \mathrm{bc}$ \\
\hline 140Ru & $4.29 \mathrm{c}$ & $59 \mathrm{~b}$ & $66 \mathrm{~b}$ & $61 \mathrm{bc}$ & $1.10 \mathrm{ab}$ \\
\hline $1103 \mathrm{P}$ & $4.05 \mathrm{c}$ & $58 \mathrm{~b}$ & $63 \mathrm{bc}$ & $64 \mathrm{~b}$ & $1.04 \mathrm{bc}$ \\
\hline $3309 C$ & $5.44 \mathrm{a}$ & 69 a & $75 \mathrm{a}$ & $66 a b$ & $1.16 \mathrm{a}$ \\
\hline $101 \mathrm{CU}$ & $4.65 a b c$ & $67 a b$ & $66 \mathrm{~b}$ & $64 \mathrm{~b}$ & $1.03 \mathrm{bc}$ \\
\hline 2007 & $2.70 \mathrm{c}$ & $48 \mathrm{~b}$ & $56 \mathrm{c}$ & $64 a b$ & $0.85 \mathrm{c}$ \\
\hline 2008 & $6.24 \mathrm{a}$ & $75 a$ & $76 a$ & $67 \mathrm{a}$ & $1.19 \mathrm{a}$ \\
\hline 2009 & $4.86 \mathrm{~b}$ & $72 \mathrm{a}$ & $67 \mathrm{~b}$ & $61 \mathrm{~b}$ & $1.11 \mathrm{~b}$ \\
\hline \multicolumn{6}{|l|}{ Syrah } \\
\hline Own roots & $3.84 \mathrm{c}$ & $51 \mathrm{~b}$ & $70 \mathrm{~d}$ & $59 d$ & $1.21 \mathrm{bc}$ \\
\hline $5 \mathrm{C}$ & $5.11 \mathrm{~b}$ & $54 \mathrm{~b}$ & 88 b & 78 a & $1.15 \mathrm{c}$ \\
\hline 140Ru & $5.15 \mathrm{~b}$ & $54 \mathrm{~b}$ & 85 bc & $69 \mathrm{bc}$ & $1.26 \mathrm{ab}$ \\
\hline $1103 \mathrm{P}$ & $4.34 \mathrm{bc}$ & $52 \mathrm{~b}$ & $79 \mathrm{bcd}$ & $68 c$ & $1.16 \mathrm{bc}$ \\
\hline $3309 C$ & $7.05 \mathrm{a}$ & $67 \mathrm{a}$ & $97 \mathrm{a}$ & $76 a b$ & $1.32 \mathrm{a}$ \\
\hline $101 \mathrm{CU}$ & $4.64 \mathrm{bc}$ & $55 \mathrm{~b}$ & $76 \mathrm{~cd}$ & $62 \mathrm{~cd}$ & $1.24 \mathrm{ab}$ \\
\hline 2007 & $3.40 \mathrm{c}$ & $42 \mathrm{~b}$ & $73 \mathrm{~b}$ & $68 a b$ & $1.14 \mathrm{c}$ \\
\hline 2008 & $6.90 \mathrm{a}$ & $75 \mathrm{a}$ & $86 a$ & $66 \mathrm{~b}$ & $1.32 \mathrm{a}$ \\
\hline 2009 & $4.41 \mathrm{~b}$ & $47 \mathrm{~b}$ & $87 \mathrm{a}$ & $72 \mathrm{a}$ & $1.21 \mathrm{~b}$ \\
\hline \multicolumn{6}{|l|}{ Chardonnay } \\
\hline Own roots & $5.37 \mathrm{a}$ & $91 \mathrm{a}$ & $57 \mathrm{~b}$ & 58 & 1.01 \\
\hline $5 \mathrm{C}$ & $5.25 \mathrm{a}$ & $79 \mathrm{~b}$ & $65 a$ & 58 & 1.11 \\
\hline $140 R u$ & $3.83 \mathrm{~b}$ & $65 c$ & $55 \mathrm{~b}$ & 54 & 1.05 \\
\hline $1103 \mathrm{P}$ & $4.14 \mathrm{~b}$ & $68 \mathrm{bc}$ & $57 \mathrm{~b}$ & 59 & 1.04 \\
\hline $3309 \mathrm{C}$ & $4.17 \mathrm{~b}$ & $70 \mathrm{bc}$ & $54 \mathrm{~b}$ & 52 & 1.03 \\
\hline $101 \mathrm{CU}$ & $4.35 \mathrm{~b}$ & $73 \mathrm{bc}$ & $56 \mathrm{~b}$ & 55 & 1.07 \\
\hline 2007 & $3.77 \mathrm{~b}$ & $64 \mathrm{~b}$ & 57 & $67 a$ & $0.85 \mathrm{c}$ \\
\hline 2008 & $4.86 \mathrm{a}$ & $77 \mathrm{a}$ & 58 & $49 \mathrm{c}$ & $1.20 \mathrm{a}$ \\
\hline 2009 & $4.92 \mathrm{a}$ & $82 \mathrm{a}$ & 58 & $55 \mathrm{~b}$ & $1.08 \mathrm{~b}$ \\
\hline \multicolumn{6}{|l|}{ Signfa } \\
\hline$S \times R$ & $<0.001$ & $<0.001$ & $<0.001$ & $<0.001$ & 0.016 \\
\hline$Y \times S$ & $<0.001$ & $<0.001$ & $<0.001$ & $<0.001$ & $<0.001$ \\
\hline$Y \times R$ & 0.019 & 0.012 & $<0.001$ & 0.398 & 0.015 \\
\hline
\end{tabular}

aSignificance ( $p$ value) of scion $(S) \times$ rootstock $(R)$, year $(Y) \times S$, and $\mathrm{Y} \times \mathrm{R}$ interactions.

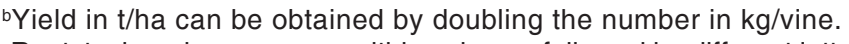
'Rootstock and year means within columns followed by different letters differ significantly at $p<0.05$ by Duncan's new multiple range test. cluster than Syrah and Chardonnay, but Syrah set more fruit than did Merlot and Chardonnay (Table 5). The percentage fruit set in Merlot and Syrah was lowest in 2008 and highest in $2009(p<0.001)$, while Chardonnay fruit set varied little from year to year. The rootstock did not alter fruit set in Syrah, but own-rooted Merlot set $\sim 8 \%$ more fruit than did its grafted counterparts $(p<0.05)$, whereas Chardonnay had $\sim 9 \%$ lower fruit set on 140Ru than on other rootstocks or own roots $(p<0.05)$. In Merlot and Syrah, the number of berries per cluster was not a reliable indicator of fruit set $(r<0.11$, n.s.), but instead was more closely associated with the number of flowers per cluster ( $\mathrm{r}>0.64, p<0.001)$. In Chardonnay, both flower number $(\mathrm{r}=0.43, p<0.001)$ and percentage fruit set $(\mathrm{r}=0.48, p<0.001)$ contributed equally to the variation in berry number.

Except in own-rooted vines of all cultivars, cluster weights varied far less from year to year than did cluster numbers (Table 4). Because of compensating effects of flower numbers and fruit set, the number of berries per cluster was much less dependent on seasonal effects than on scion cultivar and rootstock, although the interannual variation was quite pronounced (1.4-fold) in Chardonnay (Table 4). Chardonnay had fewer berries per cluster $(56 \pm 1.2)$ than Merlot $(64 \pm 0.9)$ and Syrah $(69 \pm 1.2)$. Own-rooted Merlot and Syrah had fewer berries per cluster than grafted vines, while vines on $5 \mathrm{C}$ and 3309C typically had the most berries per cluster (Table 4). The variation in berry weights was again dominated by seasonal effects: berries were smallest in 2007 and largest in 2008 with a mean range of 1.4-fold in Merlot and Chardonnay and 1.2fold in Syrah (Table 4). Syrah consistently had heavier berries than the other cultivars $(p<0.001)$. Merlot and Syrah gener-

\begin{tabular}{|c|c|c|c|}
\hline & $\begin{array}{l}\text { Flowers } \\
\text { /cluster }\end{array}$ & $\begin{array}{l}\text { Flower size } \\
\text { (mg) }\end{array}$ & $\begin{array}{c}\text { Fruit set } \\
(\%)\end{array}$ \\
\hline \multicolumn{4}{|l|}{ Merlot } \\
\hline 2007 & $265 c^{c}$ & $0.30 \mathrm{c}$ & $38 \mathrm{~b}$ \\
\hline 2008 & $475 \mathrm{a}$ & $0.40 \mathrm{a}$ & $33 \mathrm{c}$ \\
\hline 2009 & $358 \mathrm{~b}$ & $0.37 \mathrm{~b}$ & $43 a$ \\
\hline \multicolumn{4}{|l|}{ Syrah } \\
\hline 2007 & 233 & $0.32 \mathrm{c}$ & $57 a b$ \\
\hline 2008 & 264 & $0.44 \mathrm{a}$ & $53 \mathrm{~b}$ \\
\hline 2009 & 245 & $0.42 \mathrm{~b}$ & $61 \mathrm{a}$ \\
\hline \multicolumn{4}{|c|}{ Chardonnay } \\
\hline 2008 & 261 & 0.56 & 39 \\
\hline 2009 & 258 & 0.59 & 42 \\
\hline \multicolumn{4}{|l|}{ Signf ${ }^{b}$} \\
\hline $\mathrm{S}$ & $<0.001$ & $<0.001$ & $<0.001$ \\
\hline $\mathrm{R}$ & 0.076 & 0.005 & 0.408 \\
\hline $\mathrm{S} \times \mathrm{R}$ & 0.270 & 0.479 & 0.580 \\
\hline$Y \times S$ & $<0.001$ & $<0.001$ & 0.351 \\
\hline $\mathrm{Y} \times \mathrm{R}$ & 0.056 & 0.230 & 0.291 \\
\hline
\end{tabular}

aFlower caps not collected for Chardonnay in 2007.

bSignificance ( $p$ value) of scion $(S)$ and rootstock $(R)$ effects and $S$ $\times R$, year $(Y) \times S$, and $Y \times R$ interactions.

'Year means within columns followed by different letters differ significantly at $p<0.05$ by Duncan's new multiple range test. 
ally produced slightly heavier berries on 3309C than on other rootstocks or on their own roots. Consequently, own-rooted Merlot and Syrah tended to have the smallest clusters, and vines grafted to $5 \mathrm{C}$ and $3309 \mathrm{C}$ the largest (Table 4). In Merlot, the latter two rootstocks were also associated with $21 \%$ higher yields compared with other rootstocks or own roots, whereas Syrah on 3309C produced $61 \%$ more crop than on other rootstocks or own roots. Rootstocks did not influence berry numbers and berry weights on Chardonnay clusters. Nonetheless, yields of own-rooted and 5C-grafted Chardonnay were $28 \%$ higher in comparison with other rootstocks (Table 4). Across scion cultivars, own-rooted vines produced lower yields than grafted vines in 2007 but not in 2008 and 2009. Average yields in all three cultivars and across rootstocks were lowest in 2007, but the annual variation was more pronounced in Merlot (2.3-fold) and Syrah (2-fold) than in Chardonnay (1.3-fold). Merlot and Syrah yields were highest in 2008, while Chardonnay yields were similar in 2008 and 2009.

Most of the variation in the yield:pruning-weight ratio (Y/P) was due to seasonal effects followed by rootstock effects. The Y/P was generally lowest in 2007 and highest in 2008 (Table 3); the mean varied 2.5-fold in Merlot, 2.3-fold in Syrah, and 1.4-fold in Chardonnay. All three scion cultivars had higher $\mathrm{Y} / \mathrm{P}$ on $3309 \mathrm{C}$ and $140 \mathrm{Ru}$ than on other rootstocks (Merlot $+35 \%$, Syrah $+49 \%$, Chardonnay $+81 \%$; $p<0.001$ ), with own-rooted vines consistently at the low end (Table 3 ). For all cultivars, there were significant positive correlations between pruning weight and cluster number as well as yield in the following season, and these correlations generally became stronger over time (data not shown). Although yields on an individual vine basis varied from 0 to $34 \mathrm{t} / \mathrm{ha}$ in Merlot, from 0 to $40 \mathrm{t} / \mathrm{ha}$ in Syrah, and from 0 to $25 \mathrm{t} / \mathrm{ha}$ in Chardonnay, there was no sign of higher yields leading to lower pruning weights. On the contrary, higher-yielding vines were associated with higher pruning weights the following winter: $r=0.67$ for Merlot, $r=0.72$ for Syrah, and $r=0.75$ for Chardonnay (all $p<0.001$ ). Thus, larger vines had a greater yield potential than smaller vines, and higher yields did not compromise vine size and capacity for the subsequent year.

Fruit ripening and composition. Variation in fruit ripening was dominated by scion and year effects. Rootstocks contributed little to this variation and to within-vineyard variation (data not shown). Sugars typically accumulated rapidly during the first 30 to 35 days of the ripening period, but accumulation slowed markedly thereafter and effectively ceased 40 days after veraison in Chardonnay, 40 to 45 days after veraison in Merlot, and 45 to 50 days after veraison in Syrah. The rate of sugar accumulation (Brix/d) was positively correlated with the rate of organic acid degradation (g TA/L/d), but the degree of this association varied by cultivar: $r=0.58$ for Merlot; $\mathrm{r}=0.29$ for Syrah; $\mathrm{r}=0.88$ for Chardonnay (all $p$ $<0.001)$. The low yields in 2007 and, to a lesser extent, the high temperatures in 2009 accelerated sugar and anthocyanin accumulation and acid degradation compared with 2008 in Merlot and Syrah, but merely advanced the onset of ripening in Chardonnay. Although berries of all cultivars also had a higher $\mathrm{pH}$ during the initial ripening phase of 2009, $\mathrm{pH}$ was lower during that period when compared at similar TA or TSS concentrations $(p<0.001)$. While TA declined rapidly during the early ripening phase, the decrease slowed around 16 to 18 Brix and essentially ceased at $\sim 20$ to 21 Brix, irrespective of cultivar, rootstock, and year. Nonetheless, $\mathrm{pH}$ consistently continued to increase to at least 24 to 26 Brix. Over the entire ripening period, correlations between TSS and pH (transformed to $\left.\left[\mathrm{H}^{+}\right]\right)$were generally higher $(\mathrm{r}>0.92, p<0.001)$ and less variable from year to year than were correlations between TA and $\mathrm{pH}(\mathrm{r}>0.84, p<0.001)$. Anthocyanins in Merlot and Syrah berries increased during ripening but usually reached a plateau at 22 to 24 Brix. In Syrah this plateau shifted to 28 Brix in 2007, when anthocyanins accumulated more slowly but to a similar final level compared with the other years.

With few exceptions there was no clear rootstock effect on sugar and anthocyanin accumulation or organic acid degradation in the fruit (data not shown). Significant scion $\times$ rootstock and year $\times$ rootstock interactions indicated that rootstock effects were neither consistent among scion cultivars nor among growing seasons within a cultivar. In 2007, fruit from Syrah on 3309C had lower TSS and pH throughout most of ripening compared with other rootstocks and own roots $(p<0.05)$ and began the ripening phase with higher TA than own-rooted Syrah $(p<0.01)$. In 2008, grapes from own-rooted Merlot had the highest $\mathrm{pH}$ throughout ripening, and the difference increased over time ( $p<0.001)$. Ripening grapes from own-rooted Syrah had higher TSS than did grapes from grafted Syrah $(p<0.001)$; the former, together with $5 \mathrm{C}$, also had the lowest TA $(p<0.05)$, highest $\mathrm{pH}(p$ $<0.01)$, and highest anthocyanin concentrations $(p<0.001)$. Sugar accumulation and acid degradation in Chardonnay was faster on its own roots, $101 \mathrm{CU}$, and $140 \mathrm{Ru}$ than on the other rootstocks $(p<0.05)$, and grapes from own-rooted Chardonnay had a higher $\mathrm{pH}$ throughout ripening $(p<0.001)$. In 2009, $140 \mathrm{Ru}$ was associated with more rapid acid degradation than 1103P and 5C in Syrah, and 140Ru and 1103P led to faster acid degradation compared with other rootstocks or own roots in Chardonnay $(p<0.05)$. The $\mathrm{pH}$ increased more slowly in grapes from own-rooted compared with grafted Chardonnay, but it started from a higher level at veraison $(p<0.05)$. In Merlot, by contrast, the $\mathrm{pH}$ was similar across rootstocks at veraison, but increased more rapidly in own-rooted vines $(p<$ 0.001). Berries from Syrah grafted to 101CU had the highest anthocyanin concentrations throughout ripening $(p<0.01)$.

For the most part, differences in fruit composition among rootstocks disappeared by harvest (Table 6; rootstock data not shown). However, there was a significant scion $\times$ rootstock interaction on $\mathrm{pH}$ : each year fruit from own-rooted Merlot and Chardonnay had the highest $\mathrm{pH}(p<0.001)$, but that was not true for Syrah. Merlot grafted to 140Ru consistently had the lowest $\mathrm{pH}$ ( 0.2 units below own-rooted vines) followed by 3309C ( $p<0.001)$; 3309C also consistently led to a slightly lower $\mathrm{pH}$ in Syrah $(p<0.05)$, but there were no differences among rootstocks in grafted Chardonnay. The $\mathrm{pH}$ was always positively correlated with $\left[\mathrm{K}^{+}\right](0.32<\mathrm{r}<0.70, p<0.001$ to $0.05)$ and often but not always inversely correlated with TA $(-0.89<\mathrm{r}<0.05, p<0.001$ to 0.75$)$. Fruit from Merlot on its 
own roots had the lowest TA, while $140 \mathrm{Ru}$ was consistently associated with the highest TA at harvest $(p<0.001)$. No significant differences were found among rootstocks for any other fruit composition variable in any scion cultivar.

The following relationships partly reflected the low crop and associated rapid ripening in 2007, but correlations of similar magnitude and direction as those reported across years were often found within years. Across years there were negative correlations between yield and TSS (Merlot: $\mathrm{r}=-0.60$; Syrah: $\mathrm{r}=-0.52$; Chardonnay: $\mathrm{r}=-0.26$; all $p<0.001)$ and between yield and $\mathrm{pH}$ (Merlot: $\mathrm{r}=-0.38$; Syrah: $\mathrm{r}=-0.53$; Chardonnay: $\mathrm{r}=-0.24$; all $p<0.01$ ) but not TA. Somewhat weaker negative correlations were also found between $\mathrm{Y} / \mathrm{P}$ and TSS for Merlot $(\mathrm{r}=-0.51, p<0.001)$ and Syrah $(\mathrm{r}=-0.48$, $p<0.001)$, but not for Chardonnay. Still the $\mathrm{pH}$ decreased with increasing $\mathrm{Y} / \mathrm{P}$ in all cultivars (Merlot: $\mathrm{r}=-0.51$; Syrah: $\mathrm{r}=-0.24$; Chardonnay: $\mathrm{r}=-0.42$; all $p<0.01)$, while $[\mathrm{K}+]$ decreased significantly only in Merlot $(\mathrm{r}=-0.34, p<0.001)$ and Syrah $(\mathrm{r}=-0.21, p<0.001)$. The $\mathrm{pH}$ increased as canopy density (shoots $/ \mathrm{m})$ increased in Merlot $(\mathrm{r}=0.50, p<0.001)$ and Chardonnay $(\mathrm{r}=0.39, p<0.001)$, but not in Syrah. This association was partly driven by the higher shoot number (Table 3) and higher $\mathrm{pH}$ of own-rooted Merlot and Chardonnay compared with grafted vines.

There were positive correlations between average postveraison (but not preveraison) $\Psi_{\mathrm{x}}$ and TSS (Merlot: $\mathrm{r}=0.46$; Syrah: $\mathrm{r}=0.38$; Chardonnay: $\mathrm{r}=0.59$; all $p<0.01$ ). Yet TA was positively correlated with both preveraison $\Psi_{\mathrm{x}}$ (Merlot: $\mathrm{r}=0.58$; Syrah: $\mathrm{r}=0.55$; Chardonnay: $\mathrm{r}=0.59$; all $p<0.001$ ) and postveraison $\Psi_{\mathrm{x}}$ (Merlot: $\mathrm{r}=0.64$; Syrah: $\mathrm{r}=0.42$; all $p$ $<0.01$; Chardonnay: n.s.). Anthocyanins were negatively correlated with both preveraison $\Psi_{\mathrm{x}}$ (Merlot: $\mathrm{r}=-0.51$; Syrah: $\mathrm{r}$ $=-0.46$; all $p<0.001)$ and postveraison $\Psi_{\mathrm{x}}($ Merlot: $\mathrm{r}=-0.70$;

Table 6 Basic fruit composition at harvest of three scion cultivars in the Yakima Valley, WA, over three years.

\begin{tabular}{lrrrr}
\hline & $\begin{array}{c}\text { TSS } \\
\text { (Brix) }\end{array}$ & $\begin{array}{c}\text { TA } \\
(\mathbf{g} / \mathbf{L})\end{array}$ & $\mathbf{p H}$ & \multicolumn{1}{c}{$\begin{array}{c}\mathbf{K}^{+} \\
(\mathbf{g} / \mathrm{L})\end{array}$} \\
\hline Merlot & & & & \\
2007 & $25.2 \mathrm{a}^{\mathrm{b}}$ & $8.06 \mathrm{a}$ & $3.61 \mathrm{a}$ & $2.04 \mathrm{a}$ \\
2008 & $23.4 \mathrm{C}$ & $6.78 \mathrm{~b}$ & $3.52 \mathrm{~b}$ & \\
2009 & $24.5 \mathrm{~b}$ & $5.89 \mathrm{c}$ & $3.54 \mathrm{~b}$ & $1.69 \mathrm{~b}$ \\
Syrah & & & & \\
2007 & $26.7 \mathrm{a}$ & $8.33 \mathrm{a}$ & $3.54 \mathrm{~b}$ & $1.58 \mathrm{~b}$ \\
2008 & $22.1 \mathrm{C}$ & $8.43 \mathrm{a}$ & $3.49 \mathrm{C}$ & \\
2009 & $24.5 \mathrm{~b}$ & $6.95 \mathrm{~b}$ & $3.61 \mathrm{a}$ & $1.89 \mathrm{a}$ \\
Chardonnay & & & & \\
2007 & $25.4 \mathrm{a}$ & $8.47 \mathrm{~b}$ & $3.39 \mathrm{a}$ & 1.15 \\
2008 & $23.2 \mathrm{~b}$ & $9.07 \mathrm{a}$ & $3.27 \mathrm{C}$ & \\
2009 & $23.5 \mathrm{~b}$ & $8.01 \mathrm{~b}$ & $3.35 \mathrm{~b}$ & 1.25 \\
Signf & & & & \\
S & 0.055 & $<0.001$ & $<0.001$ & $<0.001$ \\
$\mathrm{R}$ & 0.288 & 0.083 & $<0.001$ & 0.072 \\
$\mathrm{~S} \times \mathrm{R}$ & 0.698 & 0.019 & $<0.001$ & 0.949 \\
Y $\times \mathrm{S}$ & $<0.001$ & $<0.001$ & $<0.001$ & $<0.001$ \\
Y $\times$ R & 0.263 & 0.905 & 0.633 & 0.204 \\
\hline
\end{tabular}

aSignificance ( $p$ value) of scion $(\mathrm{S})$ and rootstock $(\mathrm{R})$ effects and $\mathrm{S}$ $\times R$, year $(Y) \times S$, and $Y \times R$ interactions.

'Year means within columns followed by different letters differ significantly at $p<0.05$ by Duncan's new multiple range test.
Syrah: $\mathrm{r}=-0.46$; all $p<0.001)$. In Syrah, but not in the other cultivars, fruit $\left[\mathrm{K}^{+}\right]$increased as $\Psi_{\mathrm{x}}$ decreased both preveraison $(\mathrm{r}=-0.84, p<0.001)$ and postveraison $(\mathrm{r}=-0.76, p<$ 0.001 ), which was coupled to an increase in $\mathrm{pH}$ with decreasing preveraison $\Psi_{\mathrm{x}}(\mathrm{r}=-0.54, p<0.001)$ and postveraison $\Psi_{\mathrm{x}}$ $(\mathrm{r}=-0.31, p<0.05)$. Yet, none of these associations between plant water status and fruit composition were altered by grafting or the rootstocks used in this study.

\section{Discussion}

This three-year trial in a deficit-irrigated vineyard tested the influence of six rootstocks, in comparison with ownrooted vines, on water use, growth, yield formation, and fruit ripening of three $V$. vinifera cultivars. From an economic perspective, we currently cannot recommend planting $99 \mathrm{R}$ or other rootstocks with very long vegetative cycles in areas with short growing seasons and cold winters because their late shoot maturation appears to be associated with late cold acclimation and hence poor initial graft survival in winter. Overall, the remaining rootstocks induced few, and often minor, differences in scion performance. This finding was true not only for the variation among the different rootstocks, but also for the variation introduced by grafting in comparison with own-rooted vines. The variation of most variables evaluated here was clearly dominated by annual climate variation, spatial differences across the vineyard, and differences among scion cultivars. Where rootstock effects were significant and consistent from year to year, there also often was significant scion $\times$ rootstock interaction, indicating that scion cultivars modified the rootstock impact. Based on $\theta_{\mathrm{v}}$ measurements, 1103P appeared to be associated with somewhat higher soil water use, but that was not reflected in $\Psi_{x}$ measurements. The latter indicated that vines grafted to $3309 \mathrm{C}$ tended to maintain slightly higher and those grafted to $5 \mathrm{C}$ slightly lower water status than other vines. Other studies found no or inconsistent rootstock effects on vine water status (estimated as midday $\Psi_{\text {leaf }}$ ) in Chardonnay (Stevens et al. 2008), Syrah (Stevens et al. 2010), or Cabernet Sauvignon (Nuzzo and Matthews 2006, Williams 2010). However, our measures of vine vigor, such as shoot number, cane weight, and pruning weight, suggested that own-rooted vines were more vigorous than were grafted vines and $1103 \mathrm{P}$ consistently induced low vigor; 5C was often grouped with own-rooted vines and $140 \mathrm{Ru}$ with $1103 \mathrm{P}$. The $>50 \%$ higher shoot number of own-rooted Merlot and Chardonnay compared with grafted vines was especially striking. In contrast, 3309C was associated with high vigor in Syrah, intermediate vigor in Merlot, and low vigor in Chardonnay. However, over the three years both pruning weights and cane weights generally remained low by published standards.

Optimum pruning weights are thought to be in the range of 300 to $600 \mathrm{~g} / \mathrm{m}$ of canopy, and optimum cane weights fall in the range of 20 to $40 \mathrm{~g}$ (Smart 1985, Smart et al. 1990). All three scion cultivars used here had yearly average values near or below the lower limit of these ranges, and no rootstock was associated with values that exceeded their upper limit in any cultivar. In addition, despite considerable variation among 
vines, the average shoot number per unit cordon length, a measure of canopy density, was close to the optimum of 15 shoots $/ \mathrm{m}$. This suggests that in dry climates vine vigor is predominantly controlled by water deficit (and hence by irrigation), with rootstocks having only a minor effect. Moreover, the overall direction of this effect was generally one of lower vigor compared with own-rooted vines; rootstocks such as $1103 \mathrm{P}$ and $140 \mathrm{Ru}$ may decrease both scion capacity and vigor. However, $1103 \mathrm{P}$ and $140 \mathrm{Ru}$ led to higher vigor than did 5C in unirrigated Cabernet Sauvignon (Nuzzo and Matthews 2006). A recent field trial, conducted under similar climatic conditions, uncovered no differences in scion vigor among irrigated own-rooted Malbec and Malbec grafted to 140Ru, 1103P, 3309C, among other rootstocks (Di Filippo and Vila 2011).

Of the rootstocks tested in the present study, the viticultural literature often classifies 140Ru as drought tolerant, 99R and $1103 \mathrm{P}$ as intermediate to tolerant, 3309C as less to poorly tolerant, and 5C as poorly drought tolerant (e.g., Galet 1998, Whiting 2004). Yet, 99R, 1103P, and 3309C were reported to be quite drought tolerant when grafted to nonfruiting Cabernet Sauvignon and grown in sand in small pots (Carbonneau 1985). More recently, 140Ru and 1103P, and in some cases $5 \mathrm{C}$, were found to tolerate water deficit equally well when grafted to mature, fruit-bearing Chardonnay (Stevens et al. 2008), Syrah (Stevens et al. 2010), or Cabernet Sauvignon (Williams 2010). With the exception of the Malbec trial mentioned above, none of these studies included own-rooted vines for comparison. Because of its geographic origin, $V$. vinifera is likely to be more drought tolerant than many American Vitis species. Consequently, rootstocks derived from American species might tend to reduce vigor and/or vine capacity relative to own-rooted vines in arid regions, where the soil dries down sufficiently to permit implementation of deficit irrigation strategies. The low overall vigor in this study was also the reason for the high Y/P ratios, especially for grafted vines. Rather than being generally overcropped, these vines might have been classified as "undervigorous."

Low $\theta_{\mathrm{v}}$ or low temperature evidently did not limit fruit set in any year; percentage fruit set in 2007 was similar to other years, although 2007 had the lowest $\theta_{v}$ between budbreak and veraison and the lowest temperature during bloom. The low yield in 2007 was a consequence of low bud fruitfulness combined with low berry weights that resulted from low soil moisture (McCarthy et al. 1997). Much of the difference in berry size may have been established before bloom, as demonstrated by the smaller flower size in 2007 compared with the other years. Thus, while the water deficit was not severe enough to reduce fruit set, it may have been sufficient to limit flower size and hence berry size (cf. Keller et al. 2010). Rootstock effects on yield formation varied by scion cultivar, but 3309C and 5C were often associated with high yields. Yield differences arose from a combination of rootstock effects on cluster number, inflorescence size (flower number), fruit set, and berry growth. For instance, high yields of Merlot on 3309C were mostly a result of higher berry weights, whereas on $5 \mathrm{C}$ they were due to higher berry numbers per cluster; other rootstocks had inconsistent and opposing impacts on different yield components. In Syrah, 3309C resulted in the most clusters with the most flowers and hence berries, and the heaviest berries. In Chardonnay, on the other hand, 140Ru reduced the yield potential by decreasing both cluster number and fruit set, but compensatory processes in other yield components masked this rootstock effect so that final yields were similar across all rootstocks and own-rooted vines. The yield-promoting influence of 3309C on Merlot and Syrah contrasts with a cool/humid-climate rootstock trial with Müller-Thurgau (Keller et al. 2001a), in which 3309C decreased both berry number per cluster (an effect it shared with $140 \mathrm{Ru}$ ) and berry weight. In other dry-climate field trials that included some of the rootstocks used in this study with irrigated Chardonnay (Stevens et al. 2008), Syrah (Stevens et al. 2010), Cabernet Sauvignon (Williams 2010), Malbec (Di Filippo and Vila 2011), or unirrigated Cabernet Sauvignon (Nuzzo and Matthews 2006), rootstock effects on yield and its components tended to be minor and, although sometimes significant, were often inconsistent between years.

Although rootstocks may sometimes lead to considerable differences in scion yield, seasonal effects have long been deemed to strongly outweigh their influence on fruit composition (Schumann 1974). The outcomes from the present field trial confirmed this notion. Nuzzo and Matthews (2006) found that fruit ripening of Cabernet Sauvignon was quite insensitive to rootstock. Few and inconsistent rootstock effects on fruit composition were measured in a recent field trial that included own-rooted Malbec vines (Di Filippo and Vila 2011). Similar to our study, Ruhl et al. (1988) found that rootstock effects on TSS were inconsistent and that the $\mathrm{pH}$ was higher in grapes from own-rooted compared with grafted Chardonnay but not Syrah. These authors also reported a positive correlation between juice $\mathrm{K}^{+}$(and in some cases $\left.\mathrm{Na}^{+}\right)$and $\mathrm{pH}$. Potassium, sodium $\left(\mathrm{Na}^{+}\right)$, and other metal cations may substitute for $\mathrm{H}^{+}$, which increases the $\mathrm{pH}$ and thus counters the influence of organic acids (Boulton 1980a, 1980b). The higher $\mathrm{pH}$ of Merlot and Chardonnay fruit from own-rooted vines in our study might have been a consequence of greater canopy density (Smart et al. 1985, Morrison and Noble 1990) resulting from the high shoot number of these vines. However, $\left[\mathrm{K}^{+}\right]$was not significantly higher in juice from own-rooted vines. Gong et al. (2009) found similar $\mathrm{K}^{+}$ but higher $\mathrm{Na}^{+}$concentrations in fruit from own-rooted Syrah and Chardonnay compared with grafted vines, but we did not measure $\mathrm{Na}^{+}$. While grafting might have indirectly influenced fruit $\mathrm{pH}$ via canopy alterations in Merlot and Chardonnay, the $\mathrm{pH}$ was instead altered by vine water status, irrespective of rootstock, in Syrah.

The rates of sugar accumulation and organic acid (presumably malate) catabolism decreased and eventually ceased during the late ripening period. These changes were likely associated with declining sink strength of the berries $\sim 30 \mathrm{~d}$ after veraison and with declining temperatures in the fall. The continued increase in $\mathrm{pH}$ at that time may have been a consequence of continued $\mathrm{K}^{+}$(and perhaps some $\mathrm{Na}^{+}$) influx via the phloem (Rogiers et al. 2006). Moreover, the concomitant 
decrease of TSS, $\mathrm{K}^{+}$, and $\mathrm{pH}$ with increasing yield and Y/P is in agreement with earlier research (Hepner and Bravdo 1985) and indicates that higher yields and crop loads reduced phloem influx per berry. It appears that the more heavily cropped vines were source-limited, which is in agreement with the low pruning weights in this trial. This conclusion is further corroborated by the association between postveraison $\Psi_{\mathrm{x}}$ and TSS and suggests that implementation of deficit irrigation in this vineyard restricted vine growth, and consequently functional leaf area, considerably more than yield formation (Eibach and Alleweldt 1985).

\section{Conclusions}

The field performance of three $V$. vinifera cultivars (Merlot, Syrah, Chardonnay) was evaluated on six rootstocks and on their own roots in arid eastern Washington for three years. One rootstock (99R) was abandoned because of its poor winter survival as a result of its long vegetative period. Thus, rootstocks with similar characteristics cannot be recommended for regions with short growing seasons and cold winters. The remaining rootstocks induced few, and often minor, differences in scion performance. For the most part, the variation in growth, yield formation, and fruit ripening and composition was dominated by scion cultivar, spatial differences across the vineyard site, and climate variation among years. Although own-rooted vines grew more shoots than grafted vines, and $140 \mathrm{Ru}$ and $1103 \mathrm{P}$ tended to reduce scion vigor, the rootstocks generally did not impact vine phenology, fruit set, and plant water status. The influence of rootstocks on yield formation depended on the scion cultivar, but 3309C and 5C were often associated with high yields. Nevertheless, the rootstocks had only minor effects on fruit ripening and did not consistently alter soluble solids, TA, $\mathrm{K}^{+}$, or anthocyanin pigments, although the $\mathrm{pH}$ tended to be higher in fruit from ownrooted compared with grafted vines. It appears that in this dry climate vine vigor, reproductive performance, and fruit composition were mostly controlled by water deficit, through the implementation of deficit irrigation, while rootstocks had minor effects that often depended on their grafting partner.

\section{Literature Cited}

Boulton, R. 1980a. The general relationship between potassium, sodium and $\mathrm{pH}$ in grape juice and wine. Am. J. Enol. Vitic. 31:182-186.

Boulton, R. 1980b. The relationships between total acidity, titratable acidity and $\mathrm{pH}$ in grape tissues. Vitis 19:113-120.

Carbonneau, A. 1985. The early selection of grapevine rootstocks for resistance to drought conditions. Am. J. Enol. Vitic. 36:195-198.

Currle, O., O. Bauer, W. Hofäcker, F. Schumann, and W. Frisch. 1983. Biologie der Rebe. Meininger, Neustadt an der Weinstrasse, Germany.

Davenport, J.R., R.G. Stevens, and K.M. Whitley. 2008. Spatial and temporal distribution of soil moisture in drip-irrigated vineyards. HortScience 43:229-235.

Di Filippo, M., and H. Vila. 2011. Influence of different rootstocks on the vegetative and reproductive performance of Vitis vinifera $\mathrm{L}$. Malbec under irrigated conditions. J. Int. Sci. Vigne Vin 45:75-84.

Eibach, R., and G. Alleweldt. 1985. Einfluss der Wasserversorgung auf Wachstum, Gaswechsel und Substanzproduktion traubentragender Reben. III. Die Substanzproduktion. Vitis 24:183-198.
Evans, R.G., S.E. Spayd, R.L. Wample, M.W. Kroeger, and M.O. Mahan. 1993. Water use of Vitis vinifera grapes in Washington. Agric. Water Manage. 23:109-124.

Folwell, R.J., V. Cifarelli, and H. Hinman. 2001. Economic consequences of phylloxera in cold climate wine grape production areas of eastern Washington. Small Fruits Rev. 1:3-15.

Galet, P. 1998. Grape Varieties and Rootstock Varieties. [Translated from the French by J. Smith] Oenoplurimédia, Chaintré, France.

Gholami, M., Y. Hayasaka, B.G. Coombe, J.F. Jackson, S.P. Robinson, and P.J. Williams. 1995. Biosynthesis of flavour compounds in Muscat Gordo Blanco grape berries. Aust. J. Grape Wine Res. 1:19-24.

Gong, H., D.H. Blackmore, and R.R. Walker. 2009. Organic and inorganic anions in Shiraz and Chardonnay grape berries and wine as affected by rootstock under saline conditions. Aust. J. Grape Wine Res. 16:227-236.

Harbertson, J.F., and E.D. Harwood. 2009. Partitioning of potassium during commercial-scale red wine fermentations and model wine extractions. Am. J. Enol. Vitic. 60:43-49.

Harbertson, J.F., and M. Keller. 2012. Rootstock effects on deficitirrigated winegrapes in a dry climate: Grape and wine composition. Am. J. Enol. Vitic. 63:40-48.

Hepner, Y., and B. Bravdo. 1985. Effect of crop level and drip irrigation scheduling on the potassium status of Cabernet Sauvignon and Carignane vines and its influence on must and wine composition and quality. Am. J. Enol. Vitic. 36:140-147.

Keller, M., M. Kummer, and M.C. Vasconcelos. 2001a. Reproductive growth of grapevines in response to nitrogen supply and rootstock. Aust. J. Grape Wine Res. 7:12-18.

Keller, M., M. Kummer, and M.C. Vasconcelos. 2001b. Soil nitrogen utilisation for growth and gas exchange by grapevines in response to nitrogen supply and rootstock. Aust. J. Grape Wine Res. 7:2-11.

Keller, M., L.J. Mills, and D.S. Hackett. 2007. Field grafting and cold injury: Grafting height but not rootstock affects scion survival. In Proceedings of the XV International Symposium Groupe d'Etude des Systèmes de Conduite de la Vigne. B. Sladonja (ed.), pp. 294-300. Institute of Agriculture and Tourism, Poreč, Croatia.

Keller, M., J.M. Tarara, and L.J. Mills. 2010. Spring temperatures alter reproductive development in grapevines. Aust. J. Grape Wine Res. 16:445-454.

Keller, M., R.P. Smithyman, and L.J. Mills. 2008. Interactive effects of deficit irrigation and crop load on Cabernet Sauvignon in an arid climate. Am. J. Enol. Vitic. 59: 221-234.

McCarthy, M.G., R.M. Cirami, and D.G. Furkaliev. 1997. Rootstock response of Shiraz (Vitis vinifera) grapevines to dry and drip-irrigated conditions. Aust. J. Grape Wine Res. 3:95-98.

Morrison, J.C., and A.C. Noble. 1990. The effects of leaf and cluster shading on the composition of Cabernet Sauvignon grapes and on fruit and wine sensory properties. Am. J. Enol. Vitic. 41:193-200.

Nuzzo, V., and M.A. Matthews. 2006. Response of fruit growth and ripening to crop level in dry-farmed Cabernet Sauvignon on four rootstocks. Am. J. Enol. Vitic. 57:314-324.

Pongrácz, D.P. 1983. Rootstocks for Grape-vines. David Philip, Cape Town, South Africa.

Rogiers, S.Y., D.H. Greer, J.M. Hatfield, B.A. Orchard, and M. Keller. 2006. Mineral sinks within ripening grape berries (Vitis vinifera L.). Vitis 45:115-123.

Ruhl, E.H., P.R. Clingeleffer, P.R. Nicholas, R.M. Cirami, M.G. McCarthy, and J.R. Whiting. 1988. Effect of rootstocks on berry weight and $\mathrm{pH}$, mineral content and organic acid concentrations of grape juice of some wine varieties. Aust. J. Exp. Agric. 28:119-125.

Schumann, F. 1974. Beziehungen zwischen Edelreis und Unterlagen Langjährige Ergebnisse aus Adaptationsversuchen. Wein-Wissen. 29:216-229. 
Smart, R.E. 1985. Principles of grapevine canopy microclimate manipulation with implications for yield and quality. A review. Am. J. Enol. Vitic. 36:230-239.

Smart, R.E., J.K. Dick, I.M. Gravett, and B.M. Fisher. 1990. Canopy management to improve grape yield and wine quality-Principles and practices. S. Afr. J. Enol. Vitic. 11:3-17.

Smart, R.E., J.B. Robinson, G.R. Due, and C.J. Brien. 1985. Canopy microclimate modification for the cultivar Shiraz. II. Effects on must and wine composition. Vitis 24:119-128.

Stevens, R.M., J.M. Pech, M.R. Gibberd, J.A. Jones, J. Taylor, and P.R. Nicholas. 2008. Effect of reduced irrigation on growth, yield, ripening rates and water relations of Chardonnay vines grafted to five rootstocks. Aust. J. Grape Wine Res. 14:177-190.

Stevens, R.M., J.M. Pech, M.R. Gibberd, R.R. Walker, and P.R. Nicholas. 2010. Reduced irrigation and rootstock effects on vegetative growth, yield and its components, and leaf physiological responses of Shiraz. Aust. J. Grape Wine Res. 16:413-425.

Wample, R.L., and R. Smithyman. 2000. Regulated deficit irrigation as a water management strategy in Vitis vinifera production. In Water Reports 22: Deficit Irrigation Practices, pp. 89-100. Food and Agricultural Organization, Rome [http://www.fao.org/DOCREP/004/ Y3655E/y3655e00.htm].

Whiting, J.R. 2004. Grapevine rootstocks. In Viticulture. Vol. 1. Resources. 2d ed. P.R. Dry and B.G. Coombe (eds.), pp. 167-188. Winetitles, Adelaide.

Williams, L.E. 2010. Interaction of rootstock and applied water amounts at various fractions of estimated evapotranspiration $\left(\mathrm{ET}_{\mathrm{c}}\right)$ on productivity of Cabernet Sauvignon. Aust. J. Grape Wine Res. 16:434-444. 